\title{
LARGE TOURISM PRECINCTS IN SOUTH-WESTERN EUROPE - GENESIS, EVOLUTION AND TERRITORIAL IMPACT
}

\author{
J-M. CARVALHO \& C.S. MARTINS \\ Universidade de Lisboa, Faculdade de Arquitectura, CIAUD, Portugal
}

\begin{abstract}
Many coastal regions in the world have witnessed the de-naturalization of vast areas through the private development of large enclosed tourism resorts (i.e., tourism precincts). In emergent economies, this type of private tourism development aims at insulating the resort from the surrounding lack of amenities and safety; in South-Western Europe it aims at adding value to a specific kind of real estate in coastal areas. The purpose of this paper is to analyse the processes and forms of territorial occupation of these tourism precincts through a morphological methodology that identifies the significant changes on the structural patterns of coastal territorial occupation both through development and through its spatial externalities. Two main purposes drive the research, namely to reach an operational definition (i.e., ethos and spatial features) of tourism precinct in South-Western Europe and to assess the need of a specific territorial tool for the parts of the coastal area where this type of private tourism development tends to concentrate through individual settlements.
\end{abstract}

Keywords: coastal areas, sustainability, territory occupation, tourism precinct, urban form.

\section{INTRODUCTION}

Tourism, as an economic activity, is seen as a territory-associated economic development opportunity. However, conflicts concerning urban and environmental pressure, seasonality, overhead of infrastructure, land speculation and fragmented occupation patterns have placed major challenges to the planning and management of tourism spaces. These and other problems can only be overcome through the adoption of a sustainable development perspective in tourism. Despite the rapid integration of this new paradigm into public policy, the persistence of incongruous practices of planning and management of tourist areas, namely in Portugal, remains evident.

In comparison with other countries in southern Europe, the Portuguese urbanization process induced by tourism and leisure practices occurred from the 1960s of the 20th century, firstly focused in the Algarve region, leading to a progressive transformation of the natural coastal areas resulting into settlements with different design and architectural expressions, under the evolution of the perspective on the relationship between land use and tourism, as shown in other studies [1-3].

Tourism has evidenced a very high spatial and seasonal impact that can dim its benefits. There are several examples showing major conflicts on the coastal physical environment concerning tourism developments that, through ineffective planning, jeopardise the sustainability of coastal tourism destinations. The direct pressure on natural resources, particularly soil and water, on sensitive areas, may lead to significant landscape and biodiversity losses, 
besides tourism driven-urbanization contributing to the urban sprawl in coastal areas. The latter feature brings functional inefficiencies (e.g. on planning and management of public infrastructure or waste production) that tourism seasonality intensifies.

Furthermore, it is frequently accepted that economic criteria should prevail for tourism development against environmental ones, which are mostly envisaged as a permit requirement to be dealt with through mitigation procedures once the tourism development layout has been settled. This context summons for a good territorial planning framework to achieve the sustainable development of coastal areas.

Figure 1 illustrates the urban sprawl derived from incremental second-homes urban settlements, a much sought after real estate development business allowed in Portugal prior to 1991, which very often occurred around ancient fishery villages. The phenomenon of expansion of second homes in coastal Southern Europe has been discussed previously [4]. By contrast, Fig. 2 shows a tourism precinct planned ex novo outside the urban perimeter which had a significant territorial impact through the connections it required or the transformations it induced on local networks. Despite its multiple spatial configurations, there is a common perception that these developments settle on the most valuable sites and tend to disregard the need for an efficient articulation between basic networks or for the optimal provision of collective facilities and amenities, threatening the sustainability of territorial occupation.

However, both the features associated with urban form (i.e., in terms of location, land use and spatial structure) and those related to management, have evolved along time, due to market trends and to the upgrade of regulation that supports the spatial planning, tourism and urbanization policies.

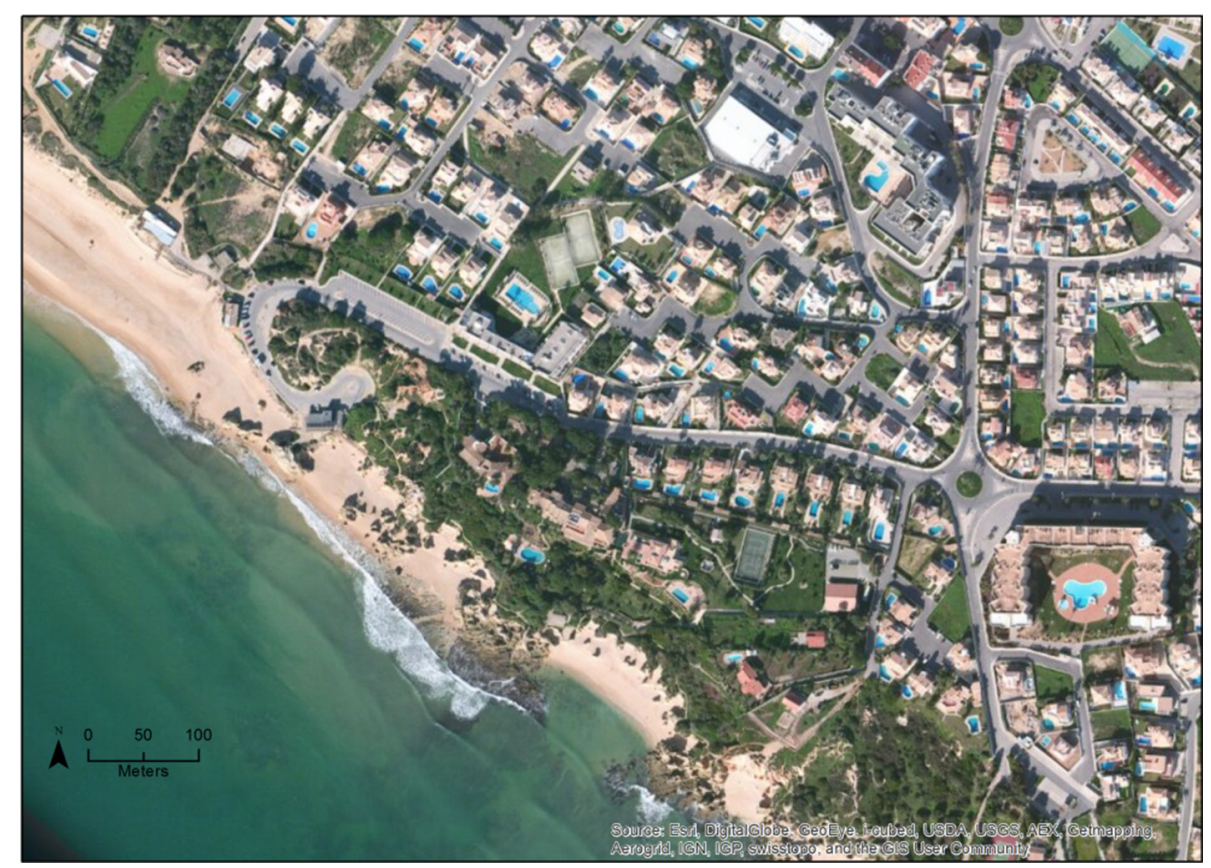

Figure 1: Example of a second-homes urban settlement (Galé, Algarve region) [5]. 


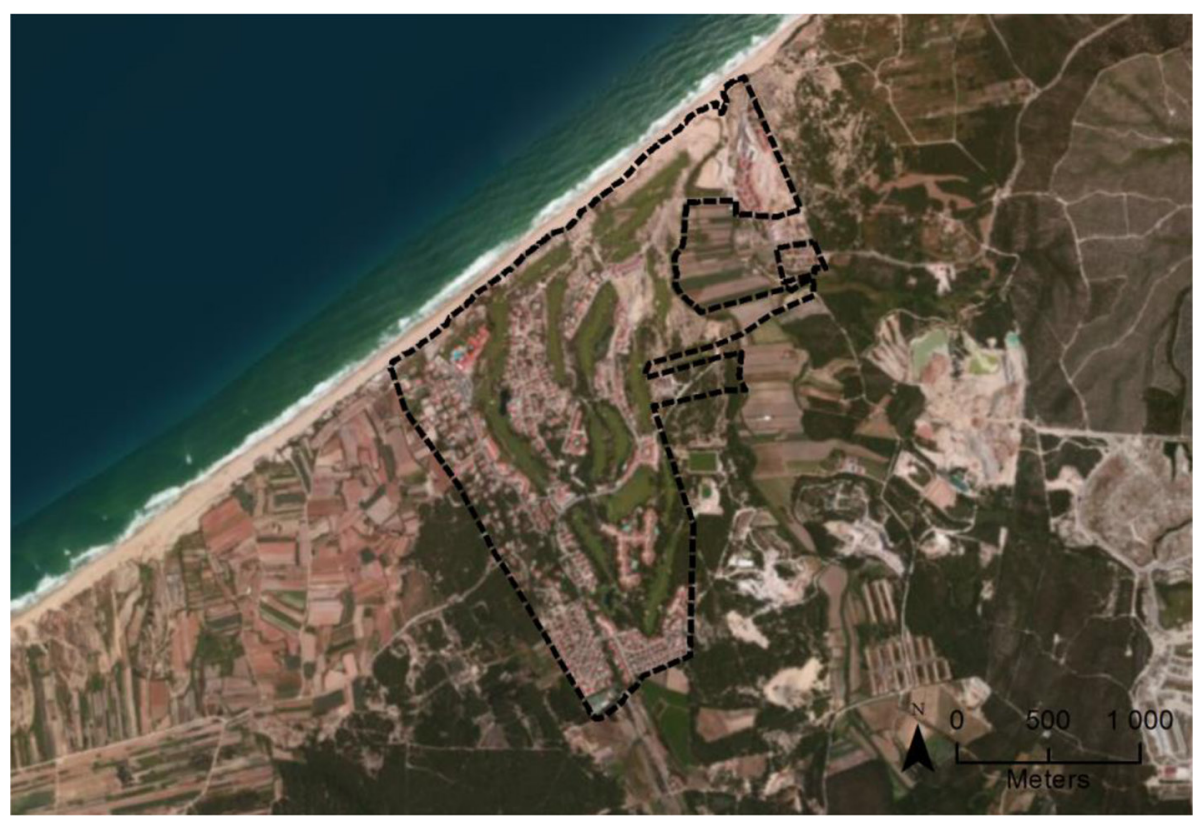

Figure 2: Example of a tourism precinct planned ex novo outside the urban perimeter (Praia d'El Rey Beach \& Golf Resort, Oeste region) [5].

\section{AIM AND METHODOLOGY}

The main research concern of this study is how to develop coastal tourism patterns that will encompass economic and social benefits with environmental sustainability. The methodology relies on the pivotal analysis of enclosed tourism resorts located on Portuguese coastal areas. They are paradigmatic case studies where challenges and contradictions regarding tourism planning are highlighted, since they are insulated autonomous spatial units, generated outside the urban structure, with a specific settlement pattern which diverges from traditional city patterns in terms of dynamics, functionality and design. This specificity itself is a research item on tourism spatial planning.

The research has two objectives: (1) to develop a conceptual approach to 'large tourism precints' in the south-western European context; and (2) to find territorial models that have in mind the tourism and real estate business rationales and allow for studying the sustainability impacts of the several tourism settlement patterns.

The core of the methodology is a morphological analysis developed by Cavaco and Martins [6] that approaches the spatial and procedural dimensions of enclosed tourism resorts, through the use of a multiscale matrix aiming at allowing for a cross-cutting reading of three major spatial and functional vectors, namely Networks, Uses and Densities. The analysis incorporates three scales: the macro-scale that corresponds to an extensive area containing several tourism developments; the medium-scale that focuses on the spatial structure of the settlement; the micro-scale that studies the lot or land parcel. This leads to the systematization of territorial development models that can be related to the business rationale (tourism and real estate) associated with the coastal urbanization process. 
The morphological analysis was developed through the work on eleven case studies, set in three municipalities of the Portuguese Coast: Grândola (Alentejo region), Loulé (Algarve region) and Óbidos (Centre region). This selection represents the different types of resorts defined by Carvalho [7] according to their own genesis, in terms of both the urbanization process and the tourism and spatial planning framework policies. The expected results may provide guidelines for tourism planning within a sustainable territorial development strategy.

\section{LARGE ENCLOSED TOURISM RESORTS (TOURISM PRECINCTS)}

This work addresses large enclosed tourism resorts. However, it is clear that the concept of resort has a different meaning according to the geographic context. According to Hornillos [8], the resort is affiliated to specific places, the «Destination resorts», which provide food, accommodation, sports, entertainment and shopping, covering the visitor's needs (e.g. Costa Adeje, Tenerife - Spain). «Megaresorts» have later on emerged, with a very large size, occasionally featuring large-scale attractions (casino, golf courses, multiple accommodations) in a seemingly (though not so exclusive and luxurious) environment, under package-tour schemes. The same author studied, in particular, the «urbanization resort model» (ibid.) that we can find in the region of Murcia (Spain), which moves away from the mass tourism at the coast but still close enough. The development is carefully planned to provide a high quality of life by presenting a new territorial configuration defined by a low-building density associated with the presence of a golf course.

Within this study, framed by the Portuguese circumstances, we envisage two types of resort which have been identified by Carvalho [7]. Those types have in common an ex novo development dependent on an urban plan and the inclusion of a very important real estate component. The differences between them derive from their genesis and evolution. The first type is the «Multi-resort development» which is a rare type of resort, installed from the second half of the last century; the resorts of this type were initially based on a public bottom-up plan, which met diverse market contexts and regulatory constraints along time. It emerged from one huge property as an autonomous tourism destination, resulting in a set of different tourism developments, although with a single developer at the beginning (e.g. Vale do Lobo - 450 hectares, 1962; Vilamoura - 1.600 hectares, 1966 and Quinta do Lago - 645 hectares, 1975; all located in the Algarve region).

The second one and the most recent is the «one-property resort development (OPRD)» which dates back from 1997, when the legal regime institutionalized the tourism settlement as compulsorily composed by hotel, apartments and/or villas and supporting facilities. This type corresponds to a tourism venture based on a permit-submitted master-plan and led by a single developer. But it was only after 2002 that these ventures could fully resort to the legal figure of allotment in rural land, which had been forbidden since 1991. This possibility was envisaged as a new business opportunity for real estate developers who therefore stepped into the tourism resort development business. In 2008, perhaps due to an unstopping chain of resort permit submissions, a new tourism law came into force, introducing new obligations that mitigated the real estate component of the resorts and strengthened their hospitality component. This was overdue, since the economic crisis was already cooling the sector.

The «historical resort» type - which can be defined as an organic settlement associated with elite tourism (as opposed to the 'Sun and Beach' mass tourism) and which grew from preexisting urban fabrics, based on exceptional landscape, location and historical features that were thoroughly maintained - has been excluded from this study for not fulfilling the requirements on insulation from the surrounding areas, large size within purposeful property 
boundaries, no-other uses within the scheme besides tourism and leisure, hospitality as a secondary business concern vis-à-vis the sale of properties within the scheme, very low density, or signature leisure and sport amenities as marketing tools. [6,7]

The above-mentioned requirements feature a tourism precinct. The term 'precinct' derives etymologically from the Latin praecingere, which means to encircle and which is commonly applied to areas with specific functions, namely tourism accommodation [9-11].

\section{TOURISM RESORTS DEVELOPMENT MODELS}

\subsection{Territorial development models}

The study of the tourism urban form conducted by Cavaco \& Martins [6] allowed for a greater knowledge on coastal tourism resorts in Portugal developed from the 1960s onwards. Three different territorial development models were identified based on their spatial and procedural attributes, namely the integrated model, the fragmented model and the mixed model. The use of these three categories highlighted some essential urban form features of tourism areas (e.g. networks or land use) and the importance of their interaction with the territorial structure they are inserted into.

The description of those territorial development models, illustrated in Fig. 3, evidences the physical and spatial specificity of tourism resorts which differentiates them from other tourism-driven developments, besides hinting at their current problems. The models have a core analytical instrumental role and allow for incorporating the evolution of the tourism business rationales.

The integrated model stands for urban developments that incorporate several tourism precincts within a global masterplan, even if the latter has undergone revision to comply with successive sector regulation and market changes. They tend to be ex novo business ventures supported by large landholdings with acknowledged landscape and accessibility advantages; the former stages of the development work as an anchor to further developments over a large area. The central feature is the articulation between the tourism settlements and the sub-

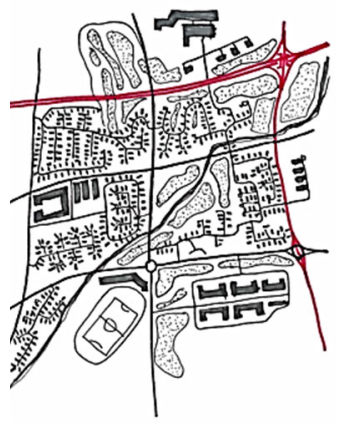

Integrated Model

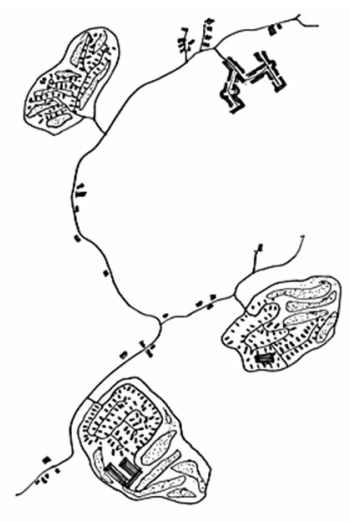

Fragmented Model

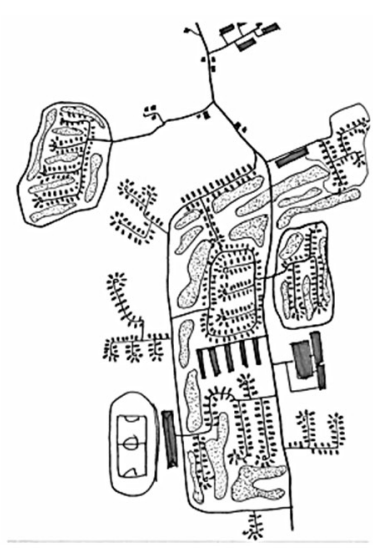

Mixed Model

Figure 3: Schematic representation of the territorial development models [6]. 
regional spatial networks. At the municipality of Loule the integrated model finds some examples, through 'polarization and functional interdependency, since the urban structure is usually articulated and integrated within the municipal network of roads and accesses' (ibid.). The integration extends to the complementary relationship among tourism resorts to share community and tourism facilities and services and to diversify the accommodation supply (ibid.). The problems associated with this model mostly derive from the bonds to the initial development and masterplan, in some cases dating back to the 1960s (even if having undergone further adaptations or revisions) when there were less urban density-related problems and environmental concerns. Those problems can be illustrated with buildings or golf courses installed on sedimentary coastlines and cliffs and with construction densities that would not be permitted or even designed in contemporary developments. This brings, to the integrated model territories, the need of urban requalification and environmental enhancing. It also brings, to municipalities, the need to upgrade the sub-regional infrastructure network coverage, since urban development around the resorts significantly increased when reported to the epoch of the launching of the resorts. Like this, the negative issues have been being mitigated or fixed over the years.

The fragmented model is characterized by a set of detached large enclosed tourism resorts, typically associated with independent land-parcelling and building developments planned in an autonomous way. This model is therefore based on a system of inward-looking enclaves with defined boundaries (fences or walls) serviced by a filamentous structure of road accesses with no explicit functional connections to the surrounding areas. Each tourism precinct has its own signature amenity (mostly golf courses). Nearly all case studies are recent interventions implemented at the end of the 90s, namely at the Óbidos or Grândola municipalities (ibid.). The main negative result is a fragmented territory where the urban system is unable to provide the integration of infrastructure and social amenities networks. This can be illustrated through a perceived lack of basic facilities (e.g., health care) which would not be felt within an efficient network or through a repetition of tourism premises that (though said to create critical mass to the destination) risks oversupply. The development of local infrastructure networks has been incrementally adapted on an ad hoc basis.

The mixed model combines features and issues from the previous models, as we can see in Tróia (Grândola municipality) which displays, despite the scenic and environmental value, an amalgam of different tourism settlements that have been incrementally generated along the last decades. The spatial strategy actually combines interaction and enclosure - e.g., the settlement identity seems to be anchored on a green corridor that also supports the accessibility and internal mobility; however the internal road network is laid out as cul-de-sac roads or ring roads enhancing reclusiveness.

\subsection{Tourism, real estate business rationales and the territorial models}

Hospitality is the traditional tourism business, providing accommodation and other hotel services in pleasant or purposeful locations. This core business evolved (namely in Southern Europe and mostly at coastal locations) to add to the hotel accommodation business the sale of temporary rights to accommodation premises, so that the owners of those rights could, besides using them, obtain income from the hospitality operation of those premises, more often than not under the hotel management. The next step (partly derived from the non-real estate character of the temporary rights, which made sales difficult) was to sell real estate units with the same aims (i.e. owners' fruition or income asset). The business margins were 
attractive and the real estate component of tourism started to prevail over the hospitality one, as far as territorial occupation is concerned. Spain led this process in Europe, whereas Portugal only started in the final 1990s [7]. Until 1991, Portuguese real estate developers were able to cater to end-users and small land investors through the supply of land lots in the coastal areas; they saw tourism as a different business - mainly hospitality or the sale of small built real estate units gathered around a hotel or dependent on its services.

However, after 2002 but foretold since 1999, the supply of land lots in coastal areas became possible again, if included in a tourism venture which the Portuguese law itself decided (in 2008) to call 'resort'. The tourism venture requirements were taken by real-estate developers as costs or as high-risk business components, to be diluted in the main real-estate business of land lots for villas (though within a mix comprising townhouses and apartments). This strategy (i.e. diluting costs) led to resorts with huge areas, generating a coastal occupation very different from the previously existing side-by-side apartments or townhouses nucleated around a hotel. In 2008, the resort permit requirements were made dearer, to be made lighter in 2009 and in 2014, but without contesting the type of occupation. Besides the occupation model, another concern has in-between arisen on sustainability, derived from many resorts incompleteness (ibid.).

This evolution of the tourism business spatial rationales meets the above-mentioned territorial model types, since the dominant hospitality approach tends to correspond to the integrated territorial model and the dominant real-estate approach tends to correspond to the fragmented territorial model. It is therefore possible to find a correspondence between the tourism business regulation (which influences business rationales) and the spatial occupation of coastal areas for tourism purposes under different business rationales. This calls for the need to assess the sustainability risks of each rationale, namely through the type of territorial model it generates.

\section{SUSTAINABLE TOURISM DEVELOPMENT AND TERRITORIAL MODELS}

\subsection{Sustainability approach}

Countries with unspoilt coastline are in an enviable position since valuable land for tourism development is still available to play a significant role in their social and economic progress. Tourism competitiveness is nevertheless very dependent upon the quality of the natural, economic, social and cultural environment. This requires close attention to be paid to the way tourism settlements are developed or evolve. The sustainability approach may support a conceptual grid to serve this concern, through providing a specific evaluation process. Sustainable development indicators concerning planning and management aspects are therefore needed. When reported to the abovementioned territorial development models, the indicators should be able to support an evaluation process that allows for classifying the formers' sustainability and to monitor it.

The fragmented model includes tourism ventures, mostly OPDR resorts, which assumed sustainability as an intrinsic part of the business strategy (e.g. environmental and energetic certifications, green-building practices, wastewater re-use or rainwater harvesting); yet it has brought deep changes in land cover and land use on coastal areas, disregarding the regional dimension of ecosystems and creating a specific type of urban sprawl (concentrated urban settlements, dispersed in rural areas). The integrated model includes ancient tourism ventures in need of sustainability upgrades, but which are integrated into structured urban settlements, 
supported by infrastructure and facilities networks; however these very often meet overloads during the high season (e.g., water demand, or waste management).

The indicators to evaluate the models' sustainability should address the above-mentioned issues. We depart, for this purpose, from the European Tourism Indicator System Toolkit for Sustainable Destinations [12]. This study covers four main categories, which are: Destination Management, Economic Value, Societal / Cultural Impact and Environmental Impact. The issues we are mostly concerned with reference to the Destination Management and Environmental Impact categories.

\subsection{Sustainability of the territorial development models}

One of the major concerns which stem from the morphological analysis is the integration of the tourism developments into the territorial structure, either on what refers to built networks (Destination Management) or on what refers to the landscape and natural areas (Environmental Impact). Both regard the spatial organization of each elemental structure of a territorial system, such as basic infrastructures, services and facilities, or shared spaces as green areas and ecosystems. These elements, which may be dealt with as networks, are crucial components for the sustainability approach to territory [6]. The degree of their integration reflects the sustainability of the territorial occupation. The integration may be envisaged as twofold, either on management or on functionality. As management issues, we have the challenge of network provision within highly seasonal contexts, the costs of the urban sprawl-led incremental network extensions, or the costs derived from business features inflicted by regulation on tourism developments (e.g., compulsory minimum size of hotels in resorts with real estate). As functionality issues, we have the enhancing of polarization within the urban structure, or the incorporation of landscape values and ecosystems (i.e., on a larger-than-site scale) in tourism developments' design.

The network integration under this perspective may be approached through the territorial models, by using indicators that allow for measuring it. These indicators, as based on a spatial and landscape perspective, might complement the European Indicator System [12] ones, mostly based on the actions by local enterprises of the tourism sector. Table 1 presents a tentative approach to indicators that may be incorporated into the Destination Management and Environmental Impact categories, reflecting the above-mentioned aims.

This system also intends to enable a comparison of the three territorial models, yet dependent on the adequate data collection.

\section{CONCLUSION}

The morphological approach to territorial occupation sustainability may be a tool for spatial planning and monitoring. Three territorial models have been used to make that approach operational. To meet the aims of an efficient spatial planning, adequate sustainability indicators must be defined and used in the assessment of the models.

All along the present work, the tourism destination boundaries have been assumed and therefore not argued. This is, however, a major issue when spatial planning is concerned and must be duly dealt with on a par with the morphological approach. It deserves a research on its own, with two departing requirements - the destination should be bottom-up delimited by the stakeholders and the within territory should be able to support a sustainable tourism activity, as defined above and having in mind the tourism business rationales.

As a preliminary conclusion, we would say that it seems that the fragmented model implies a greater risk to sustainability, since it provides lower integration when compared to the inte- 
Table 1: Indicators to assess the territorial development models sustainability.

\begin{tabular}{ll}
\hline Destination management category \\
\hline Criteria & Indicators \\
\hline & $\begin{array}{l}\text { Number of cycling and pedestrian pathways connecting different } \\
\text { tourism ventures or urban nucleus within the destination } \\
\text { Green mobility / Urban system }\end{array}$ \\
& $\begin{array}{l}\text { Percentage of the destination covered with public facilities (e.g., } \\
\text { healthcare, social) }\end{array}$ \\
Integration of the & Facilities / Urban system \\
territorial structure & Percentage of new tourism ventures resorting to formerly existing \\
& basic infrastructure \\
& Infrastructures / Urban system \\
& Percentage of the destination developed under a global master plan \\
& Spatial planning \\
\hline Environmental impact category \\
\hline Criteria & Indicators \\
\hline Integration of the & $\begin{array}{l}\text { Percentage of natural areas in the destination } \\
\text { landscape and }\end{array}$ \\
ecosystem & $\begin{array}{l}\text { Pocal biodiversity } \\
\text { bilitation operations } \\
\text { Local biodiversity } \\
\text { Percentage of construction area or buildings made of materials with } \\
\text { reduced ecological footprint } \\
\text { Natural resources } \\
\text { Percentage of energy-efficient construction area or buildings } \\
\text { Natural resources }\end{array}$ \\
&
\end{tabular}

grated or mixed models. Within the latter, problems seem not to be as intense as in the others and there is more flexibility to enhance benefits.

\section{REFERENCES}

[1] Brito, S., Sustentabilidade, ordenamento do território e ambiente, SPI - Sociedade Portuguesa de Inovação Consultadoria Empresarial e Fomento da Inovação: Porto, pp. 17-22, 2010 (on line).

[2] Cavaco, C., Turismo, desenvolvimento regional e local (Chapter). Geografia de Portugal: planeamento e ordenamento do território, dir. C. Medeiros, Círculos de Leitores e Autores: Lisboa, pp. 400-427, 2006.

[3] Lobo S., A colonização da linha de costa: da marginal ao "resort". Journal Arquitectos, 227, pp. 18-25, 2007.

[4] Roca, M., Oliveira J., Roca, Z. \& Costa, L., Second home tourism in the Oeste region, Portugal: features and impacts. European Journal of Tourism, Hospitality and Recreation, 3(2), pp. 35-55, 2012. 
[5] GOOGLE EARTH, www.google.com/earth/.

[6] Cavaco, C., Martins, C.S. Grandes Empreendimentos e Resorts - Dimensões de análise e desafios para o planeamento dos espaços turísticos em áreas costeiras: A Dimensão Forma. Personal communication, 31 October 2014, Workshop Espacetur - Planeamento dos espaços turísticos em áreas costeiras, Faculdade de Arquitetura, Lisboa: 2015.

[7] Carvalho, J-M., The regulation of tourism settlements in the Portuguese territory: tradeoffs and inefficiencies. Sustainable Development and Planning, 7, pp. 941-952, 2015. http://dx.doi.org/10.2495/sdp150791

[8] Hornillos, M.J., El Modelo Urbanizador "Resort” Análisis, Contexto Y Repercusiones En El Campo De Murcia Y Mar Menor. Universidad Politécnica de Cartagena, Cartagena: pp. 21-35, 2010 (online).

[9] Hayllar, B. \& Griffin, T., The Precinct Experience: a phenomenological approach. Tourism Management, 26, pp. 517-528, 2005. http://dx.doi.org/10.1016/j.tourman.2004.03.011

[10] McDonnell, I., Leisure and tourism GNVQ. Annals of Tourism Research, 24(1), 1997. http://dx.doi.org/10.1016/S0160-7383(97)81449-1

[11] McLeod, C., Nolan G. \& Bartholomew M., Sustainable tourism precincts in rural and regional areas: case studies in Australia and New Zealand. CRC for Sustainable Tourism Pty Ltd: Australia, pp. 8-16, 2008. http://dx.doi.org/10.1016/S0160-7383(97)81449-1

[12] DG Enterprise \& Industry, European Tourism Indicator System. Toolkit for sustainable destinations, European Union, Bruxelles, 2013. (online). 